
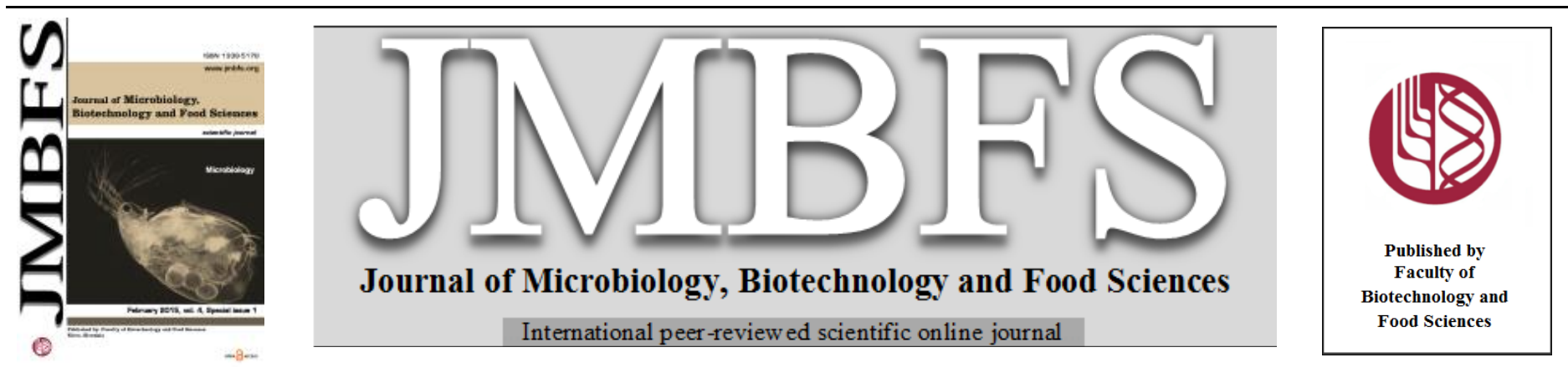

\title{
ENDOGENAL COLONIZATION OF GRAPES BERRIES
}

\section{Dana Tančinová*, Lubomír Rybárik, Zuzana Mašková, Soňa Felšöciová, Miroslava Císarová}

Address(es): prof. Ing. Dana Tančinová, PhD.,

Department of Microbiology, Faculty of Biotechnology and Food Sciences, Slovak University of Agriculture in Nitra, Tr. A. Hlinku 2, 94976 Nitra, Slovakia, phone number: +42137641 4433.

*Corresponding author: dana.tancinova@uniag.sk

doi: 10.15414/jmbfs.2015.4.special1.69-73

\section{ARTICLE INFO}

Received 20.11.2014

Revised 17. 12. 2014

Accepted 25. 12. 2014

Published 2. 2. 2015

Regular article OPEN $\partial_{\text {ACCESS }}$

\begin{abstract}
The aim of study was to detect the microscopic filamentous fungi from wine surface of sterilized grapes berries of Slovak origin. We analyzed 21 samples of grapes, harvested in the year 2012 of various wine-growing regions. For the isolation of species we used the method of direct plating surface-sterilized berries (using 0.4\% freshly pre-pared chlorine) on DRBC (Dichloran Rose Bengal Chloramphenicol agar). The cultivation was carried at $25 \pm 1^{\circ} \mathrm{C}$, for 5 to 7 days. A total number of 2541 fungal isolates pertaining to 18 genera including Mycelia sterilia were recovered. Isolates of genus Alternaria were found in all of tested samples with the highest relative density $56.4 \%$. The second highest isolation frequency we detected for genus Fusarium ( $90.48 \%$ positive samples), but with low relative density (31 isolates and 2.99\% RD). Another genera with higher isolation frequency were Cladosporium (Fr $85.71 \%$, RD 14.6\%), Mycelia sterilia (Fr 85.71\%, RD 4.25\%), Penicillium (Fr 80.95\%, RD 13.42\%), Botrytis ( $\mathrm{Fr} 71.43 \%, \mathrm{RD} 2.95 \%$ ) Rhizopus ( $\mathrm{Fr}$ 66.66\%, RD 1.34\%), Aspergillus (Fr 57.14\%, RD 0.87\%), Epicoccum ( $\operatorname{Fr} 47.62 \%, \mathrm{RD} 1.22 \%$ ), Trichoderma (Fr 42.86\%, RD 1.26\%). Isolation frequency of another eight genera (Arthrinium, Dichotomophtora, Geotrichum, Harzia, Chaetomium, Mucor, Nigrospora and Phoma) was less than $10 \%$ and relative density less than $0.5 \%$. Chosen isolates of potential producers of mycotoxin (species of Alternaria, Aspergillus, Fusarium and Penicillium) were tested for the ability to produce relevant mycotoxins in in vitro conditions using TLC method. None isolate of Aspergillus niger aggregate (13 tested) did not produce ochratoxin A - mycotoxin monitored in wine and another products from grapes berries. Isolates of potentially toxigenic species recovered from the samples were found to produce another mycotoxins: aflatoxin $\mathrm{B}_{1}$, altenuene, alternariol, alternariol monomethylether, citrinin, diacetoxyscirpenol, deoxynivalenol, HT-2 patulin, penitrem A and T-2 toxin in in vitro conditions. In conclusion, another research should be performed to detect the occurrence of these mycotoxins in grapes, must, wine and another products from grape.
\end{abstract}

\section{INTRODUCTION}

The grape microbiota is complex and includes filamentous fungi, yeasts and bacteria with different physiological characteristics and effects on wine production (Rousseaux et al., 2014; Barata et al., 2012). Contamination of grapes by different moulds occurs during preharvesting, harvesting and grape processing. The fungal growth begins in grapes if temperature and humidity are suitable. Rotting and spoilage of grape berries before harvest can be caused by a variety of fungal species such as Alternaria spp., Aspergillus spp., Botrytis cinerea, Cladosporium spp., Eurotium spp., Penicillium spp. and Rhizopus spp. (Magnoli et al., 2003; Rousseaux et al., 2014). The concern about filamentous fungi in the vineyard has been traditionally linked to spoilage of grapes due to fungal growth. However, the discussion in the European Union concerning the establishment of a maximum limit for the presence of the mycotoxin ochratoxin A (OTA) in wines has increased concern about mycotoxin production. Mycotoxins are secondary metabolites produced by filamentous fungi that have been detected in food commodities, including grapes and wine (Serra et al., 2005). Ochratoxin A is a secondary metabolite produced by filamentous fungi of the genera Aspergillus and Penicillium present in a wide variety of foodstuffs (Amézqueta $\boldsymbol{e t ~ a l . , ~ 2 0 1 2 ) . ~ I t ~ h a s ~ b e e n ~ c l a s s i f i e d ~ a s ~ a ~ p o s s i b l e ~ h u m a n ~ c a r c i n o g e n ~}$ (group 2B) by the International Agency of Research of Cancer (IARC, 1993). Black aspergilli were the dominant genus among the filamentous fungi isolates from grapes and were the only potential OTA-producing fungi found (Lasram $\boldsymbol{e} t$ al., 2007).

The aim of this study was to investigate endogenous microscopic filamentous fungal colonization of grapes grown in small and medium-sized vineyards in Slovakia in year 2012 with the focus on genera Aspergillus, Alternaria, Fusarium and Penicillium. The ability of isolates of potentially toxigenic species to produce the most important mycotoxins was determined by the means of thin layer chromatography.

\section{MATERIAL AND METHODS}

Samples

We analyzed 21 samples of grapes, harvested in year 2012 from various winegrowing regions of Slovakia, from small and medium-sized vineyard. We analyzed grape variety Alibernet (1 sample), André (2 samples), Blaufrankise (5), Cabernet Sauvignon (1), Müller Thurgau (1), Velsch Riesling (1), Grüner Veltliner (3), , Pálava (1), Pinot gris (1), Pinot noir (1), Saint Laurent (1), Sauvignon (1), Tramin (1), Zala gyöngye (1). Samples (3 kg) were collected at the time of technological ripeness.

\section{Mycological analysis}

For the isolation of species we used the method of direct plating berries, surfacesterilized berries (using $0.4 \%$ freshly pre-pared chlorine) on DRBC (Dichloran Rose Bengal Chloramphenicol agar). The cultivation was carried at $25 \pm 1^{\circ} \mathrm{C}$, for 5 to 7 days in dark. After incubation colonies of Aspergillus, Alternaria, Fusarium and Penicillium were transferred onto appropriate identification media.

\section{Identification of Alternaria species}

Isolates were re-inoculated on PCA - potato-carrot agar (Samson et al., 2002) and cultured for 7 days at room temperature and natural light. Main used identification keys were Andersen et al. (2001), Andersen et al. (2002), Simmons (1994), and Simmons (2007). 


\section{Identification of Aspergillus species}

Conidial suspensions were inoculated at three equidistant points both on Czapekyeast extract agar (CYA) (Samson et al., 2002), Czapek-yeast with 20\% Sucrose (CY20S) (Samson et al., 2002) and malt extract agar (MEA) (Samson $\boldsymbol{e t}$ al., 2002), and incubated in dark at $25{ }^{\circ} \mathrm{C}, 7$ days. Species identification was done according to Klich (2002), Pitt et Hocking (2009), Samson et al. (2002, 2010), Samson et Varga (2007).

\section{Identification of Penicillium species}

The penicillia belonging to Aspergilloides, Furcatum and Biverticillium subgenera were inoculated at three equidistant points both on Czapek-yeast extract agar (CYA), malt extract agar (MEA) and Creatine Sucrose agar (CREA) (Samson et al., 2002) and incubated in dark at $25^{\circ} \mathrm{C}$. Sub-cultivation on CYA at $37^{\circ} \mathrm{C}$ was used as well. Species identification was done after 7 days according to Pitt et Hocking (2009), Samson et al. (2002, 2010) and Frisvad et Samson (2004).

\section{Identification of Fusarium species}

Potato Dextrose agar (PDA) (Samson $\boldsymbol{e}$ t al., 2002) was used for observation of colony characteristics. "Synthetischer nährstoffarmer agar" (SNA) (Samson $\boldsymbol{e}$ al., 2002) was used for micromorphological features. Cultures were incubated at $25{ }^{\circ} \mathrm{C}$ in dark (PDA) and UV-light $365 \mathrm{~nm}$ (SNA). Species identification was done after 7 days according to Leslie et Summerell (2006), Nelson et al. (1983), Pitt et Hocking (2009) and Samson et al. (2002, 2010).

The obtained results were evaluated and expressed in isolation frequency ( $\mathrm{Fr})$ and relative density (RD) at the genus or species level. The isolation frequency $(\%)$ is defined as the percentage of samples within which the species or genus occurred at least once. The relative density (\%) is defined as the percentage of isolates of the species or genus, occurring in the analyzed sample (Gautam et al., 2009). These values were calculated according to González et al. (1996) as follows:
$\operatorname{Fr}(\%)=(\mathrm{ns} / \mathrm{N}) \times 100$
$\mathrm{RD}(\%)=(\mathrm{ni} / \mathrm{Ni}) \times 100$

where $\mathrm{ns}=$ number of samples with a species or genus; $\mathrm{N}=$ total number of samples; $\mathrm{ni}=$ number of isolates of a species or genus; $\mathrm{Ni}=$ total number of isolated fungi.

\section{Mycotoxins screening by a modified agar plug method}

The abilities of selected isolates of potentially toxigenic species to produce relevant mycotoxins in in vitro conditions were screened by the means of thin layer chromatography (TLC) according to Samson et al. (2002) modified by Labuda et Tančinová (2006).

Cultivation for screening of extracellular metabolites (aflatoxin $\mathrm{B}_{1}$, aflatoxin $\mathrm{G}_{1}$, altenuene, alternariol, alternariol monomethylether, citrinin, diacetoxyscirpenol, deoxynivalenol, HT-2, patulin, T-2 toxin ochratoxin A) were carried out on YES (Yeast Sucrose agar) (Samson et al., 2002) and for intracellular (cyclopiazonic acid and penitrem A) on CYA (Czapek-yeast extract agar); conditions of cultivation in dark at $25^{\circ} \mathrm{C}, 14$ days. In each tested isolate, 3 pieces of mycelium together with cultivation medium of area of approximately $5 \times 5 \mathrm{~mm}$ were cut from colonies and extracted in $1000 \mathrm{ml}$ of extraction agents (as referred to Table 1) on vortex for 2 minutes. $20 \mu \mathrm{l}$ of liquid phase of extracts along with standards (Sigma, Germany) were applied on TLC plate (Marchey-Nagel, Germany) and consequently developed in solvent system (see Table 1). Visualisation of extrolites was carried out referred on Table 1 and compared with standards.

Table 1 Extraction agent, solvents and visualisation of mycotoxins as determined by the agar plug method

\begin{tabular}{|c|c|c|c|}
\hline Mycotoxin & $\begin{array}{l}\text { Extraction } \\
\text { agent }\end{array}$ & Solvents & Treatments of visualisation \\
\hline Aflatoxin B1 & ch:m & TEF & UV light (365 nm) (blue spot) \\
\hline Aflatoxin G1 & ch:m & TEF & UV light $(365 \mathrm{~nm})$ (green spot) \\
\hline cyclopiazonic acid & ch:m & TEF & directly in daylight after spraying with the Ehrlich reagent (violet -tailed spot) \\
\hline Patulin & ch:m & TEF & $\begin{array}{l}\text { by spraying with } 0.5 \% \text { methylbenzothiazolone hydrochloride in methanol, heated at } \\
130^{\circ} \mathrm{C} \text { for } 8 \mathrm{~min} \text { and then detectable as a yellow-orange spot on daylight }\end{array}$ \\
\hline Penitrem A & ch:m & TEF & $\begin{array}{l}\text { after spraying with } 20 \% \mathrm{AlCl}_{3} \text { in } 60 \% \text { ethanol, heated at } 130{ }^{\circ} \mathrm{C} \text { for } 8 \mathrm{~min} \text { and then } \\
\text { detectable as a dark green to black spot on daylight }\end{array}$ \\
\hline Citrin & ch:m & TEF & UV light $(365 \mathrm{~nm})$ (yellow-green tailed spot) \\
\hline Altenuene & ch:m & TEF & UV light(365 nm) (blue spot) \\
\hline Alternariol & ch:m & TEF & UV light (365 nm) (blue spot) \\
\hline $\begin{array}{l}\text { Alternariol } \\
\text { monomethylether }\end{array}$ & ch:m & TEF & UV light (365 nm) (blue spot) \\
\hline Deoxynivalenol & ch:m & TAM & $\begin{array}{l}\text { after spraying with } 20 \% \mathrm{AlCl}_{3} \text { in } 60 \% \text { ethanol, heated at } 130{ }^{\circ} \mathrm{C} \text { for } 8 \mathrm{~min} \text { and then } \\
\text { detectable as a blue spot under UV light }(365 \mathrm{~nm})\end{array}$ \\
\hline Diacetoxyscripenol & ch:m / a:w & TAM & $\begin{array}{l}\text { after spraying with } 20 \% \mathrm{AlCl}_{3} \text { in } 60 \% \text { ethanol, heated at } 130{ }^{\circ} \mathrm{C} \text { for } 8 \mathrm{~min} \text {, then } \\
\text { spraying with } 20 \% \mathrm{H}_{2} \mathrm{SO}_{4} \text { in water heated at } 130{ }^{\circ} \mathrm{C} \text { for } 8 \mathrm{~min} \text {, and then detectable as } \\
\text { a blue green spot under UV light }(365 \mathrm{~nm})\end{array}$ \\
\hline HT-2 toxin & $\mathrm{a}: \mathrm{w}$ & TAM & $\begin{array}{l}\text { spraying with } 20 \% \mathrm{H}_{2} \mathrm{SO}_{4} \text { in water heated at } 130{ }^{\circ} \mathrm{C} \text { for } 8 \mathrm{~min} \text {, and then detectable as } \\
\text { a blue green spot under UV light }(365 \mathrm{~nm})\end{array}$ \\
\hline $\mathrm{T}-2$ toxin & $\mathrm{a}: \mathrm{w}$ & TAM & $\begin{array}{l}\text { spraying with } 20 \% \mathrm{H}_{2} \mathrm{SO}_{4} \text { in water heated at } 130{ }^{\circ} \mathrm{C} \text { for } 8 \mathrm{~min} \text {, and then detectable as } \\
\text { a blue green spot under UV } \operatorname{light}(365 \mathrm{~nm})\end{array}$ \\
\hline
\end{tabular}

\section{RESULTS AND DISCUSSION}

Sound grapes are an essential prerequisite for the production of high-quality wines. However, pricing of grapes is so far mainly based on the must weight of grape deliveries, although e.g. highly botrytised grapes become raisined bringing about higher contents of soluble solids than sound ones. Besides the desired "noble rot", in particular infection of unripe fruits by grape rot decreases the perceptual quality by destroying fruit flavours typical of the grape variety, furthermore leading to off-flavours, off-odour, bitterness and colour-loss. Moreover, the formation of mycotoxins, particular ochratoxin A, associated with fungal infestation highly affects food safety of the products (Porep et al., 2014). The filamentous fungi identified from surface disinfection grapes berries are indicated in Table 2 and relative density of isolated genera in Figure 1 . Altogether 2541 isolates were recovered and assigned to 18 fungal genera, including Mycelia sterilia (isolates without sporulation).

Table 2 Filamentous fungi identified from surface disinfected grape berries

\begin{tabular}{lccccc}
\hline Genera / species & $\begin{array}{c}\text { Number } \\
\text { of isolates }\end{array}$ & $\begin{array}{c}\text { Isolation } \\
\text { frequency }(\%)\end{array}$ & Genera / species & $\begin{array}{c}\text { Number } \\
\text { of isolates }\end{array}$ & $\begin{array}{c}\text { Isolation } \\
\text { frequency (\%) }\end{array}$ \\
\hline Alternaria & $\mathbf{1 4 3 3}$ & $\mathbf{1 0 0}$ & Geotrichum & $\mathbf{4}$ & $\mathbf{9 . 5 2}$ \\
\hline Al. alternate & 196 & 80.95 & Harzia & $\mathbf{3}$ & $\mathbf{9 . 5 2}$ \\
\hline Al. arborescens & 168 & 47.62 & Chaetomium & $\mathbf{1}$ & $\mathbf{4 . 7 6}$ \\
\hline Al. infectoria & 51 & 23.81 & Mucor & $\mathbf{3}$ & $\mathbf{9 . 5 2}$ \\
\hline Al. tenuissima & 944 & 100 & Mycelia sterilia & $\mathbf{1 0 8}$ & $\mathbf{8 5 . 7 1}$ \\
\hline
\end{tabular}




\begin{tabular}{|c|c|c|c|c|c|}
\hline Al. sp. & 74 & 80.95 & Nigrospora & 1 & 4.76 \\
\hline Arthrinium & 2 & 9.52 & Penicillium & 341 & 80.95 \\
\hline Aspergillus & 22 & 57.14 & P. aurantiogriseum & 31 & 4.76 \\
\hline A. clavatus & 2 & 4.76 & P. brevicompactum & 12 & 4.76 \\
\hline A. flavus & 6 & 19.05 & P. canescens & 1 & 4.76 \\
\hline A. niger aggregate & 13 & 47.62 & P. citrinum & 2 & 9.52 \\
\hline A. sp. & 1 & 4.76 & P. corylophilum & 16 & 4.76 \\
\hline Botrytis & 75 & 71.43 & P. crustosum & 5 & 14.29 \\
\hline Cladosporium & 371 & 85.71 & P. expansum & 95 & 38.1 \\
\hline Dichotomophtora & 1 & 4.76 & P. funiculosum & 2 & 9.52 \\
\hline Epicoccum & 31 & 47.62 & P. glabrum & 1 & 4.76 \\
\hline Fusarium & 76 & 90.48 & P. griseofulvum & 1 & 4.76 \\
\hline F. acuminatum & 4 & 14.29 & P. chrysogenum & 128 & 33.3 \\
\hline F. avenaceum & 2 & 9.52 & P. oxalicum & 5 & 4.76 \\
\hline F. graminearum & 7 & 14.29 & P. polonicum & 1 & 4.76 \\
\hline F. oxysporum & 1 & 4.76 & P. solitum & 2 & 4.76 \\
\hline F. proliferatum & 15 & 38.1 & P. variabile & 1 & 4.76 \\
\hline F. semitectum & 2 & 9.52 & $P . \mathrm{sp}$. & 38 & 33.3 \\
\hline F. solani & 2 & 4.76 & Phoma & 3 & 9.52 \\
\hline F. sporotrichioides & 13 & 38.1 & Rhizopus & 34 & 66.66 \\
\hline F. subglutinans & 1 & 4.76 & Trichoderma & 32 & 42.86 \\
\hline F. verticillioides & 1 & 4.76 & \multicolumn{2}{|c|}{ Total identified isolates } & 2541 \\
\hline F. sp. & 28 & 57.14 & \multicolumn{2}{|c|}{ Total berries analysed } & 1050 \\
\hline
\end{tabular}

Legend: Al. - Alternaria, A. Aspergillus, F. - Fusarium, P. - Penicillium, sp. - species

Isolates of the genera Aspergillus, Alternaria, Fusarium and Penicillium significant producers of mycotoxins have been identified to the species level. Isolates of genus Alternaria were found in all of tested samples with the highes relative density $56.4 \%$. The second highest isolation frequency we detected for genus Fusarium (90.48\% positive samples), but with low relative density (31 isolates and $2.99 \% \mathrm{RD})$. Another genera with higher isolation frequency were Cladosporium (Fr 85.71\%, RD 14.6\%), Mycelia sterilia (Fr 85.71\%, RD 4.25\%), Penicillium (Fr 80.95\%, RD 13.42\%), Botrytis (Fr 71.43\%, RD 2.95\%) Rhizopus (Fr 66.66\%, RD 1.34\%), Aspergillus (Fr 57.14\%, RD 0.87\%), Epicoccum ( $\mathrm{Fr}$ $47.62 \%$, RD 1.22\%), Trichoderma ( $\mathrm{Fr} 42.86 \%$, RD 1.26\%). Isolation frequency of another eight genera (Arthrinium, Dichotomophtora, Geotrichum, Harzia, Chaetomium, Mucor, Nigrospora and Phoma) was less than $10 \%$ and relative density less than $0.5 \%$. According to the results Serra et al. (2005) the most frequent genera isolated from grapes for wine production were Cladosporium (25\% RD), Alternaria (24\%), Botrytis (15\%), Penicillium (9\%) and Aspergillus (8\%). Rousseaux et al. (2014) report the occurrence of 70 genera of filamentous fungi in different countries. For example the region of origin markedly influenced the spoilage fungal population to which berries are exposed (Serra et al., 2006).

Predominant mycobiota in our study belong to genus Alternaria. Similarly, Bau et al. (2005) classify this genus among the dominant grapes, isolated from $75.6 \%$ of plated berries. Magnoli et al. (2003) determined this genus from $80 \%$ analysed samples of wine grape varieties from Mendoza, Argentina. We identified four group of Alternaria: Al. alternata, Al. arborescens, Al. infectoria and Al. tenuissima. The selected isolates were tested for ability to produce mycotoxins in in vitro conditions by using TLC method (Table 4). The ability to produce altenuene, alternariol and alternariol monomethylether was found. Ostrý et al. (2007) tested presence of some Alternaria mycotoxins in fresh grape juice, must and wine (Czech origin). Occurrence of Alternaria mycotoxins was not proved.

Two species (A. clavatus, A. flavus), and Aspergillus niger aggregate were identified (1 isolate was not determinate to species level). Black aspergilli (mainly A. niger aggregate and Aspergillus carbonarius) are important producers of OTA in grapes (Lasram et al., 2007, Chulze et al., 2006, EL Khoury et al., 2008, Amézqueta et al., 2012). The ecological parameters of black aspergilla are not completely known, but some results are available and this knowledge is critical in the development and prediction of the risk models of contamination of grapes and interacting environmental parameters (Battilani et al., 2006). Presence of A. niger aggregate was detected in $47.62 \%$ of samples, but none of them does not produce OTA in in vitro conditions (Table 3). Serra et al. (2005) from the Aspergillus strains identified, the most frequent were from section Nigri (84\%), namely bisseriate species $A$. carbonarius and A. niger aggregate. Producing of aflatoxin $\mathrm{B}_{1}$ (A. flavus) and patulin (A. clavatus) by tested isolates in in vitro conditions was found. EL Khoury et al. (2008) reported ability of $43.4 \%$ of tested isolates of A. flavus (isolated from wine-grapes or musts) to produce aflatoxin $\mathrm{B}_{1}$. Three Aspergillus spp. (A. flavus and A. parasiticus) isolates from grapes had evidence of aflatoxin $\mathrm{B}_{1}$ production (Chunmei et al., 2013).

Fifteen species of penicilia were identified (Table 2). Penicillium is described as being frequent in soils and temperate regions (Serra et al., 2006). Blue mould, caused by $P$. expansum, is one of the most economically damaging postharvest diseases of pome fruits, although it may affect a wider host range, including grapes (Sanzani et al., 2013). Isolates of this species were detected from $38.1 \%$ our samples. Species of genus Penciillium (including $P$. expansum) are important producers of mycotoxins. The ability to produce mycotoxins (Table 3 ) in in vitro conditions was detected follows: $P$. citrinum - citrin, $P$. crustosum - penitrem A and $P$. expansum - patulin and citrinin. P. verrucosum potential producer of OTA was not detected in sample. Potential producers (Aspergillus and Penicillium species) of patulin from grapes detected Serra et al. (2005), too.

Ten species of fusaria were identified (Table 2). Serra et al. (2005) shown that Fusarium strains were primarily detected at the early maturation stages of grapes, with and without surface disinfection. Some of the tested isolates (Table 4) have been able to produce selected trichothecenes (diacetoxyscirpenol, deoxynivalenol, HT-2 and T-2 toxin) in in vitro conditions.

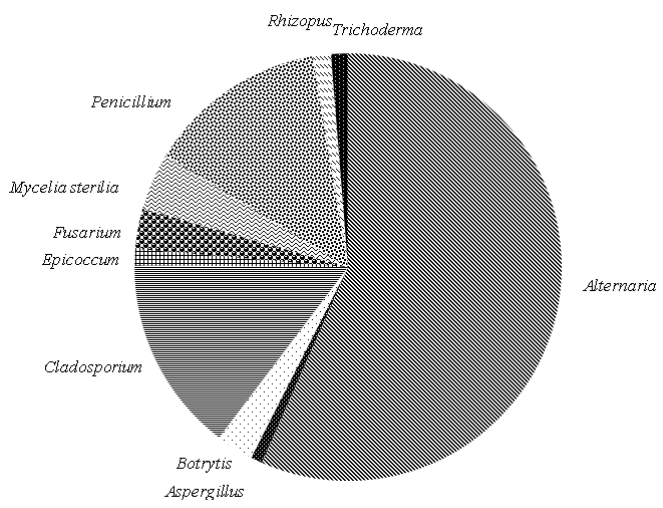

Figure 1 Relative density (RD) (\%) isolated genera from surface-sterilized grapes berries (relative densities genera Arthrinium, Geotrichum, Harzia, Chaetomium, Mucor, Nigrospora and Phoma were less 0.5\%) 
Table 3 Potential ability isolates of species of genera Aspergillus and Penicillium to produce relevant mycotoxins in in vitro conditions, tested by TLC method

\begin{tabular}{|c|c|c|c|c|c|c|c|}
\hline \multirow{2}{*}{\multicolumn{8}{|c|}{$\begin{array}{l}\text { Tested isolates } \\
\text { Aspergillus clavatus }\end{array}$}} \\
\hline & & & & & & & \\
\hline Aspergillus flavus & $1 * / 2 * *$ & $0 / 2$ & $0 / 2$ & & & & \\
\hline Aspergillus niger aggregate & & & & & $0 / 13$ & & \\
\hline Penicillium citrinum & & & & $1 / 1$ & & & \\
\hline Penicillium crustosum & & & & & & & $2 / 2$ \\
\hline Penicillium expansum & & & & $3 / 12$ & & $10 / 12$ & \\
\hline
\end{tabular}

Table 4 Potential ability isolates of species of genera Alternaria and Fusarium to produce relevant mycotoxins in in vitro conditions, tested by TLC method

\begin{tabular}{|c|c|c|c|c|c|c|c|}
\hline Tested isolates & ALT & AME & AOH & DAS & DON & T-2 & HT-2 \\
\hline Alternaria alternata & $4 * / 8 * *$ & $7 / 8$ & $7 / 8$ & & & & \\
\hline Alternaria arborescens & $6 / 7$ & $7 / 7$ & $7 / 7$ & & & & \\
\hline Alternaria infectoria & $0 / 1$ & $0 / 1$ & $0 / 1$ & & & & \\
\hline Alternaria tenuissima & $8 / 18$ & $17 / 18$ & $17 / 18$ & & & & \\
\hline Fusarium oxysporum & & & & & & $1 / 1$ & $1 / 1$ \\
\hline Fusarium proliferatum & & & & $0 / 1$ & & $0 / 1$ & $0 / 1$ \\
\hline Fusarium sporotrichioides & & & & $4 / 4$ & $2 / 2$ & $4 / 4$ & $2 / 4$ \\
\hline
\end{tabular}

\section{CONCLUSION}

From the 1050 surface-sterilized (21 samples) grape berries have been isolated 2541 strains of microscopic filamentous fungi. The highest relative density and isolation frequency was determined for species genus Alternaria. In wine the most important mycotoxin is the ochratoxin A which is not appreciably degraded during wine making, fermentation process and storage. This toxin is the only one mycotoxin monitored under EU law. Aspergillus niger aggregate isolates did not produce OTA in in vitro conditions. There were found out the ability to produce following mycotoxis: aflatoxin $\mathrm{B}_{1}$, altenuene, alternariol, alternario monomethylether, citrinin, diacetoxyscirpenol, deoxynivalenol, HT-2 patulin, penitrem A and T-2 toxin in in vitro conditions by TLC method of chosen strains of genera Alternaria, Aspergillus, Fusarium and Penicillium. In another research would be advisable to follow occurrence of these mycotoxins in grapes, must, wine and another products from grape.

Acknowledgments: This work was co-funded by European Community under project no 26220220180: Building Research Centre „AgroBioTech" and VEGA $1 / 0611 / 14$.

\section{REFERENCES}

AMÉZQUETA, S., SCHORR-GALINDO, S., MURILLO-ARBIZU, M. GONZÁLEZ-PEÑAS. E. 2012. OTA-producing fungi in foodstuffs: A review. Food Control, 26 (2), 259-268. http://dx.doi.org/10.1016/j.foodcont.2012.01.042 ANDERSEN, B., KROGER, E., ROBERTS, R. G. 2001. Chemical and morphological segregation of Alternaria alternata, A. gaisen and A. longipes. Mycological Research, 105(3), 291-299. http://dx.doi.org/10.1017/s0953756201003446

ANDERSEN, B., KROGER, E., ROBERTS, R. G. 2002. Chemical and morphological segregation of Alternaria arborescens, A. infectoria and $A$ tenuissima species-groups. Mycological Research, 2002, 106(2), 170-182. http://dx.doi.org/10.1017/s0953756201005263

BARATA, A., MALFEITO-FERREIRA, M., LOUREIRO, V. 2012. The microbial ecology of wine grape berries. International Journal of Food Microbiology, 153(3),

243-259. http://dx.doi.org/10.1016/j.ijfoodmicro.2011.11.025

BATTILANI, P., MAGAN, N., LOGRIECO, A. 2006. European research on ochratoxin A in grapes and wine. International Journal of Food Microbiology, 111, S2-S4. http://dx.doi.org/10.1016/j.ijfoodmicro.2006.02.007

BAU, M., BRAGULAT, M. R., ABARCA, M. L., MINGUEZ, S., CABAÑES, F.J. 2005. Ochratoxigenic species from Spanish wine grapes. International $\begin{array}{llll}\text { Journal of Food } & \text { Microbiology, } & 98(2), & 125-130\end{array}$ http://dx.doi.org/10.1016/j.ijfoodmicro.2004.05.015

CHULZE, S. N., MAGNOLI, C., DALCERO, A. 2006. Occurrence of ochratoxin $\mathrm{A}$ in wine and ochratoxigenic mycoflora in grapes and dried vine fruits in South America. International Journal of Food Microbiology, 111, S5-S9. http://dx.doi.org/10.1016/j.ijfoodmicro.2006.02.006

CHUNMEI, J., JUNLING, S., QI'AN, H., YANLIN, L. 2013. Occurrence of toxin-producing fungi in intact and rotten table and wine grapes and related $\begin{array}{llll}\text { influencing factors. Food } & \text { Control, } & 31(1), & 5-13 .\end{array}$ http://dx.doi.org/10.1016/j.foodcont.2012.09.015
EL KHOURY, A., RIZK, T., LTEIF, R., AZOURI, H., DELIA, M. L., LEBRIHI, A. 2008. Fungal contamination and aflatoxin B1 and ochratoxin A in Lebanes wine-grapes and musts. Food and Chemical Toxicology, 46(6), 2244-2250. http://dx.doi.org/10.1016/j.fct.2008.02.026

FRISVAD, J. C., SAMSON, R. A. 2004. Polyphasic taxonomy of Penicillium subgenus Penicillium. A guide to identification of food and air-borne terverticillate Penicillia and their mycotoxins. Studies in Mycology, 49,1-173.

GONZÁLES, H. H. L., PACIN, A., RESNIK, S. L., MARTINEZ, E. J. 1996. Deoxynivalenol and contaminant mycoflora in freshly harvested Argentinean wheat in 1993. Mycopathologia, 135(2), 129-134. http://dx.doi.org/10.1007/bf00436463

GAUTAM, A., SHARMA, S., BHADAURIA, R. 2009. Detection of toxigenic fungi and mycotoxins in medicinally important powdered herbal drugs. The Internet Journal of Microbiology, 7 (2). http://dx.doi.org/10.5580/104b

IARC. 1993. Some naturally occurring substances: Some food items and constituents, heterocyclic aromatic amines and mycotoxins. IARC Monographs on the Evaluation of Carcinogenic Risk to humans, 56, IARC, 489-522.

KLICH, M. A. 2002. Identification of common Aspergillus species. Wageningen Ponsen \& Looijen, 116 p. ISBN 90-70351-46-3. http://dx.doi.org/10.1017/s0269915x03243123

LABUDA, R., TANCINOVÁ, D. 2006. Fungi recovered from slovakian poultry feed mixtures and their toxinogenity. Annals of Agricultural and Environmental Medicine, 13, 193-200.

LASRAM, S., BELLÍ, N., CHEBIL, S., NAHLA, Z., AHMED, M., SANCHIS, V., GHORBEL, A. 2007. Occurrence of ochratoxigenic fungi and ochratoxin A in grapes from a Tunisian vineyard. International Journal of Food Microbiology, 114(3), p. 376-379. http://dx.doi.org/10.1016/j.ijfoodmicro.2006.09.027

LESLIE, J.F., SUMMERELL, B.A. 2006. The Fusarium Laboratory Manual. Australia : Blackwell Publishing, 2006. 388 p. ISBN 978-0-8138-1919-8 http://dx.doi.org/10.1002/9780470278376

MAGNOLI, C., VIOLANTE, M., COMBINA, M., PALACIO, G., DALCERO, A. 2003. Mycoflora and ochratoxin-producing strains of Aspergillus section Nigri in wine grapes in Argentina. Letter of Applied Microbiology, 37(2), 179-184. http://dx.doi.org/10.1046/j.1472-765x.2003.01376.x

MUBATANHEMA, W., MOSS, M. O., FRANK, M. J., WILSON, D. M. 1999. Prevalence of Fusarium species of the Liseola section on Zimbabwean corn and their ability to produce the mycotoxins zearalenone, moniliformin and fumonizin $\mathrm{B}_{1}$ Mycopathologia, 148(3), 157-163. http://dx.doi.org/10.1023/a:1007146419501

NELSON, P.E., TOUSSOUN, T.A., MARASAS, W.F.O. 1983. Fusarium species. An illustrated Manual for Identification. USA : The Pennsylvania State University, 1983. 193 p. ISBN 0-271-00349-9.

OSTRÝ, V., ŠKARKOVÁ, J., PROCHÁZKOVÁ, I., KUBÁTOVÁ, A., MALÍŘ, F., RUPRICH, J. 2007. Mycobiota of Czech wine grapes and occurrence of ochratoxin A and Alternaria mycotoxins in fresh grape juice, must and wine. Czech Mycol, 59(2), 241-254.

PITT, J. I., HOCKING, A. D. 2009. Fungi and food spoilage. $3^{\text {rd }}$ ed. London, New York : Springer Science + Business Media, LLC 2009, 519 p. ISBN 9780 387-92206-5. http://dx.doi.org/10.1016/j.ijfoodmicro.2010.08.005

POREP, J. U., WALTER, R., KORTEKAMP, A., CARLE, R. 2014. Ergosterol as an objective indicator for grape rot and fungal biomass in grapes. Food Control, 37, 77-84. http://dx.doi.org/10.1016/j.foodcont.2013.09.012 
ROUSSEAUX, S., DIGUTA, C. F., ZADOÏ-MATEI. 2014. Non-Botrytis graperotting fungi responsible for earthy and moldy off-flavors and mycotoxins. Food Microbiology, 38, 104-121. http://dx.doi.org/10.1016/j.fm.2013.08.013

SANZANI, S. M., MONTEMURRO, C., SOLFRIZZO, M., IPPOLITOM A.

2013. Genetic structure and natural variation associated with host of origin in Penicillium expansum strains causing blue mould. International Journal of Food Microbiology, 165(2),

http://dx.doi.org/10.1016/j.ijfoodmicro.2013.04.024

SERRA, R., BRAGA, A., VENÂNCIO, A. 2005. Mycotoxin-producing and other fungi isolated from grapes for wine production, with particular emphasis on ochratoxin A. Research in Microbiology, 156 (4), 515-521. http://dx.doi.org/10.1016/j.resmic.2004.12.005

SERRA, R., LOURENÇO, A., ALÍPIO, P., VENÂNCIO, A. 2006. Influence of the region of origin on the mycobiota of grapes with emphasis on Aspergillus and Penicillium species. Mycological research., 110(8), 971-978. http://dx.doi.org/10.1016/j.mycres.2006.05.010

SAMSON, R. A., HOEKSTRA, E. S., FRISVAD, J.C., FILTENBORG, O. 2002. Introduction to food- and airborne fungi. Utrecht : Centraalbureau voor Schimmelcultures, 2002. 389 p. ISBN 90-70351-42-0. http://dx.doi.org/10.5580/104b

SAMSON, R. A., HOUBRAKEN, U., THRANE, U., FRISVAD, J. C. ANDERSEN, B. 2010. Food and Indoor Fungi. Utrecht : CBS-KNAW Fungal Biodiversity Centre, 390 p. ISBN 978-90-70351-82-3.

SAMSON, R. A., VARGA, J. eds. 2007. Aspergillus systematics in the genomic era. Studies in Mycology, 59, Utrecht : CBS Fungal Biodiversity Centre, 206 p. ISBN 978-90-70351-69-4. http://dx.doi.org/10.1016/s0166-0616(14)60167-6

SIMMONS, E. G. 1994. Alternaria themes and variations $(106-111)$. Mycotaxon, 50, 409-427.

SIMMONS, E. G. 2007. Alternaria, An Identification Manual. Utrecht : CBS Fungal Biodiversity Centre, 775 p. ISBN 978-90-70351-68-7. http://dx.doi.org/10.1016/j.mycres.2008.06.012 